\title{
Banking reforms and bank efficiency: Evidence for the collapse of Spanish savings banks
}

\author{
Antonio Blanco-Oliver \\ University of Seville, Av. Ramón y Cajal, 1, 41018, Seville, Spain
}

\section{A R T I C L E I N F O}

\section{JEL classification:}

G21

G28

\section{Keywords:}

Banking crisis

Mergers and acquisitions

Government intervention

Efficiency

Bootstrap

\begin{abstract}
A B S T R A C T
This paper analyzes the impact of the banking system reform implemented through the banking consolidation (mergers and acquisitions) carried out in Spain to address the collapse of savings banks. The 2008 global financial crisis triggered a sovereign debt crisis in Europe and the burst of a real estate bubble in Spain, and forced a government intervention, despite policymakers not yet having developed a clear guidance for addressing banking crises. We therefore explore to what extent the efficiency of the Spanish financial system increased as the troubled savings banks merged with each other and/or were acquired by healthy savings or commercial banks. Our findings show that this Spanish banking reform impacts positively on the banking performance in terms of both bank efficiency and bank solvency. Consequently, banking reform via M\&A drives out unviable banks and is a feasible alternative that minimizes the negative effects of government interventions in the financial systems.
\end{abstract}

\section{Introduction}

Collapses of banking systems usually precipitate interventions of government and financial authorities with the ultimate goal of restoring confidence in the markets and avoiding a contagion effect on the rest of the economy. These public interventions are considered contrary to market economy principles and may result in interest conflicts and inefficiencies in resource allocation (Allen et al., 2015; Calderon \& Schaeck, 2016). In fact, part of the literature sustains that intervention measures distort the market and competence and increase risk in the banking sector (Acharya \& Yorulmazer, 2007; Gropp \& Vesala, 2004). Nevertheless, when the market economy collapses, government interventions arise as one of the few effective measurements to correct the market failures, thereby improving the functioning of the banking market as well as its competitiveness and solvency (Brei \& Schclarek, 2013).

However, resolution strategies for financially distressed banks are often carried out on an ad-hoc basis, without knowing their real economic effects. As Hryckiewicz (2014) sustained, there is not a consensus about whether government interventions impact positively on bank performance or not. That is, policymakers do not have a clear guidance regarding what programs and combination of economic mechanisms would minimize the negative consequences for the economies of the government interventions. Linked to the lack of generally accepted procedures to implement banking reforms, a key factor that must considered is the need to adapt public interventions to the institutional framework (Beck at al., 2013). As Casu and Molyneux (2003) suggested, the inconclusive findings of previous research regarding the effects of banking reforms on bank performance is due to institutional and other environmental factors. In other words, these authors argue that the effects of the financial systems' restructurings on the banking sector performance are country-dependent. These findings consequently support the need to separately address and analyze each banking reform.

Therefore, to enrich this debate we analyze whether the banking system reform conducted in Spain during 2011 and 2012 has

E-mail address: aj_blanco@us.es. 
increased the efficiency of the banking sector. In particular, the main objective of this paper is to test to what extent the efficiency of the Spanish financial system increased, or decreased, as the troubled Cajas merged with each other and/or were acquired by healthy Cajas or commercial banks. We present evidence documenting the impact of the large bank consolidation (through mergers and acquisitions) implemented in Spain under the banking system reform on both (i) bank productivity and (ii) bank solvency. To do so, a panel dataset for the period 2005-2016, with information for all savings banks and commercial banks that operated in Spain, is used to perform a twostage analysis. In the first stage, data envelopment analysis (DEA) is used to rank the lending organizations according to their technical efficiency score, which is calculated separately for each year of our research period and assuming constant returns to scale approach. In the second stage, since the efficiency scores are censored at the maximum value of the efficiency scores (1), we follow Banker et al. (2010) and run a panel Tobit and preferently a bootstrapped truncated regression (Simar \& Wilson, 2007) to analyze the effect of environmental variables on the efficiency of the banking sector.

The Spanish banking reform constitutes an ideal case study to analyze the effects of M\&A on banking efficiency due to both external and internal factors. Firstly, the impact of the Global Financial Crisis (henceforth GFC) was stronger in Europe, where it triggered a sovereign debt crisis (Arghyrou \& Kontonikas, 2012). The debt crisis particularly affected the Mediterranean countries (Italy, Spain, Portugal and Greece) whose sovereign risk premia and credit default swap rates reached record levels (Lane, 2012). Secondly, besides the CFC and sovereign debt crises, in Spain a domestic crisis also developed, caused by the real estate bubble burst. This had disastrous effects on Spanish savings banks (Cajas de ahorro) due to their high exposure to the retail mortgage market (Illueca et al., 2014). Thirdly, two institutional lending regimes coexist in the Spanish banking system (Salas \& Saurina, 2002): on the one hand, commercial and, on the other hand, savings banks, that suffered serious management problems (Ruiz et al., 2016). The triple (financial, sovereign debt and real estate) crisis and the political interferences in the management of the Cajas severely impacted on Spanish economics and forced the government to implement one of the largest banking reforms in the world in the last decades.

The relevance of the restructuring of the Spanish financial system was so intense that it brought about the demise of Spanish savings banks, despite these banking institutions representing more than $70 \%$ of the Spanish lending sector. Precisely, at the end of the banking reform process the Spanish lending sector was composed of 18 lending institutions (all of them commercial banks, except two savings banks), down from the 59 entities (45 savings banks and 14 commercial banks) that there had been at the beginning of the financial restructuring process. In other words, the Cajas were shown to be the most vulnerable part of the Spanish financial system (Martin et al., 2018). This public intervention was supported by the European Commission and ultimately consisted in executing a banking reform to tackle the Cajas' crisis and in safeguarding the financial system and economy of Spain. Of course, it also wished to avoid an economic contagion to the rest of the euro area.

This paper updates the banking literature in two ways. First, we contribute to the banking restructuring literature by showing the positive effects on both banking efficiency and solvency of government interventions. That is, our findings contradict the liberal wisdom that supports private monitoring mechanisms because they are more effective than public rules and supervision in governing banks. Our results therefore have relevant practical implications since, to date, there has not been a general agreement in the literature about the effects of banking reforms on bank performance. Second, our research also updates the literature that discusses the impact of M\&A on both banking competition and stability. In this field, researchers have yet to reach a consensus (Martinez-Miera \& Repullo, 2010). In line with Allen et al. (2011), our results suggest that bank consolidation through M\&A increases bank performance and hence the stability of the financial system. Also, it is worth mentioning that our research is timely as the lack of empirical research in this field prevents financial authorities from adopting the proper measurements for the banking sector in collapsed financial market contexts, as is currently happening in many countries due to the impact of Covid-19.

The paper proceeds as follows. Section 2 provides an overview of the Spanish financial system and also develops the hypotheses. Section 3 describes the data and the methodology applied, while section 4 shows and discusses the main results and the robustness tests conducted. Finally, Section 5 discusses and concludes by showing the practical and theoretical implications of our study.

\section{Background}

\subsection{Spanish financial system restructuring}

The first Spanish Caja (Caja de Ahorros y Previsión de Madrid) was created in 1835 through the Royal Order 3rd. of April, which calls upon the creation of a Caja in each provincial capital. Subsequently, other two laws (Royal Decree of 29th. of June of 1853 and, mainly, the Law of 1880) enhanced the institutional development of the Cajas in the lending sector.

The positioning of the Cajas in the Spanish financial intermediation industry was based on focusing on a small (region or province) geographical area and fostering the financial inclusion of the population (usually poorer people) without access to financial services. Indeed, the Cajas gained great popularity among the population since they were considered lending organizations with a strong social performance and a high level of corporate social responsibility. The Cajas fostered a greater bank office density, particularly in rural areas, and the use of relationship lending (Boot \& Thakor, 2000). Relationship lending is a financial intermediation approach under which 'banks acquire information over time through contact with the firm, its owner, and its local community on a variety of dimensions and use this information in their decisions about the availability and terms of credit' (Berger \& Udell, 2002, pp. F32). Accordingly, the Cajas' loan officers created strong personal ties with clients, who, in addition to financial services, are supported in administrative procedures such as tax payments. The economic logic that the Cajas applied was based on a higher money allocation to social welfare programs, increasing not only their profitability but also their reputation and customer satisfaction (Bachiller \& Garcia-Lacalle, 2018).

In accordance with this strong market reception, the relevance of the Cajas continuously grew during the 20th century, but it accelerated in the mid-1990s and achieved a leading role in retail banking in the years before the GFC of 2008 (Ruiz et al., 2016). This 
growth was in parallel with the socio-economic development and trade openness that took place in Spain during the 70s.

The basis of the economic liberalization of Spain coincided with two relevant events: (i) the end of Franco's dictatorship and the rise of democracy, and (ii) the first large Spanish banking crisis, which had an associated cost of 15\% of gross domestic product (Vives, 2001). During these years, a sort of open and regenerative banking policy was launched in Spain that brought the creation of new lending entities -which until then had been prohibited. But, as is theoretically demonstrated (Brown et al., 2019; Rice \& Strahan, 2010),

Table 1

Spanish restructuring process by merger and acquisitions.

\begin{tabular}{|c|c|c|c|c|c|c|}
\hline & $\begin{array}{l}\text { Type } \\
\text { entity }\end{array}$ & Lending institution & Type of agreement & Type of agreement (II) & $\begin{array}{l}\text { Type of } \\
\text { agreement (III) }\end{array}$ & $\begin{array}{l}\text { Resulting financial } \\
\text { group }\end{array}$ \\
\hline 1 & SB & Caja Madrid & IPS (Institutional Protection & Buy ordinary shares $(17,959$ & & Bankia \\
\hline 2 & SB & Bancaja & System) 4,465 MM€ & $\mathrm{MM} €)$ & & \\
\hline 3 & SB & Caja Insular Canarias & & & & \\
\hline 4 & SB & Caja Laietana & & & & \\
\hline 5 & SB & Caja Ávila & & & & \\
\hline 6 & SB & Caja Segovia & & & & \\
\hline 7 & SB & Caja La Rioja & & & & \\
\hline 8 & SB & La Caixa & Merger & Merger & & CaixaBank \\
\hline 9 & SB & Caja Girona & & & & \\
\hline 10 & SB & Caja Navarra & IPS (Institutional Protection & & & \\
\hline 11 & SB & Caja Burgos & System) 977 MM€ & & & \\
\hline 12 & SB & Caja Canarias & & & & \\
\hline 13 & SB & Caja Sol & & & & \\
\hline 14 & SB & Caja Guadalajara & & & & \\
\hline 15 & SB & Banco Valencia & $\begin{array}{l}\text { Intervened by the government } \\
(5,498 \mathrm{MM} €)\end{array}$ & & & \\
\hline 16 & SB & Cajastur & Merger & IPS (Institutional Protection & & LiberBank \\
\hline 17 & SB & CCM & & System) 1,740 MM€ & & \\
\hline 18 & SB & Caja Extremadura & & & & \\
\hline \multirow[t]{2}{*}{19} & SB & Caja Cantabria & & & & \\
\hline & SB & Ibercaja & & Merger & & Banco Ibercaja \\
\hline 20 & SB & CAI & IPS (Institutional Protection & & & \\
\hline 21 & SB & Caja Badajoz & System) $407 \mathrm{MM} €$ & & & \\
\hline 22 & SB & Caja Círculo Burgos & & & & \\
\hline 23 & SB & Caja Sa Nostra & IPS (Institutional Protection & & & Banco Mare \\
\hline 24 & SB & Caja Murcia & System) 1,645 MM€ & & & Nostrum \\
\hline 25 & SB & Caja Penedès & & & & \\
\hline 26 & SB & Caja Granada & & & & \\
\hline 27 & SB & BBK & IPS (Institutional Protection & & & KutxaBank \\
\hline 28 & SB & Cajasur & System) $800 \mathrm{MM} €$ & & & \\
\hline 29 & SB & Kutxa & & & & \\
\hline 30 & SB & Vital Kutxa & & & & \\
\hline 31 & SB & Unicaja & Merger & Merger & & Unicaja Banco \\
\hline 32 & SB & Caja Jaén & & & & \\
\hline 33 & SB & Caja Duero & Merger 525 MM $€$ & & & \\
\hline 34 & SB & Caja España & & & & \\
\hline 35 & SB & Caja Ontinyent & & & & Ontinyent \\
\hline 36 & SB & Caja Pollensa & & & & Pollensa \\
\hline 37 & $\mathrm{CB}$ & BBVA & & Merger & Merger & BBVA \\
\hline 38 & SB & Caja Sabadell & Merger 953 MM€ & & & \\
\hline 39 & SB & Caja Tarrasa & & & & \\
\hline 40 & SB & Caja Manlleu & & & & \\
\hline 41 & SB & Caja Catalunya & Merger 12,052 MM $€$ & & & \\
\hline 42 & SB & Caja Tarragona & & & & \\
\hline 43 & SB & Caja Manresa & & & & \\
\hline 47 & $\mathrm{CB}$ & Banco Sabadell & Merger & Merger & & Banco Sabadell \\
\hline 48 & $\mathrm{CB}$ & Banco Guipuzcoano & & & & \\
\hline 49 & SB & $\begin{array}{l}\text { Caja Ahorros } \\
\text { Mediterráneo }\end{array}$ & $\begin{array}{l}\text { Intervened by government } \\
(5,249 \mathrm{MM} €)\end{array}$ & & & \\
\hline 50 & $\mathrm{CB}$ & Bankinter & & & & Bankinter \\
\hline 51 & $\mathrm{CB}$ & Banco Popular & Merger (Private) & & & Banco Popular \\
\hline 52 & $\mathrm{CB}$ & Banco Pastor & & & & \\
\hline 53 & $\mathrm{CB}$ & Banco Santander & Merger (Private) & & & Banco Santander \\
\hline 54 & $\mathrm{CB}$ & Banesto & & & & \\
\hline 56 & $\mathrm{CB}$ & Deutsche Bank & & & & Deutsche Bank \\
\hline 57 & $\mathrm{CB}$ & Banca March & & & & Banca March \\
\hline 58 & $\mathrm{CB}$ & Banca Pueyo & & & & Banco Pueyo \\
\hline \multirow[t]{2}{*}{59} & $\mathrm{CU}$ & Banco Cooperativo & & & & Banco Cooperativo \\
\hline & & Español & & & & Español \\
\hline
\end{tabular}

Note: SB: Saving bank; CB: Commercial bank; CU: Credit Union. 
deregulation intensified the competition among Spanish lending organizations, which pressured the profit margins of the entities and fostered the assumption of greater risks. This, together with several factors such as (i) the low specialization of their top management teams, (ii) the focus on speculative operations in the real estate sector (scarce diversification of their loan portfolio) and, (iii) the impact of the first oil crisis -that pushed up the inflation rate to $26.4 \%$ in 1976- caused, in the 1978-1985 period, the first large Spanish banking crisis in which $51(46.36 \%)$ of a total of 110 banks collapsed. Of these 51 banks, 47 (92.16\%) entities had been recently created under the new legal-policy framework to liberalize the Spanish economy.

The economic liberalization and the crisis of the commercial banks were exploited by the Cajas which substantially increased their market share at the expense of the commercial banks (Kumbhakar et al., 2001). As Illueca et al. (2014) sustained, the factor that most strongly influenced the exponential growth of the Cajas was the deregulation of the Spanish financial system to match with the leading European countries. Particularly relevant for the nationwide expansion of the Cajas was the removal of regulatory geographic constraints that, until that date, had limited their operations to their area of origin. Cajas also benefited from the equalization of their investment requirements to commercial banks and also from the easing of reserve requirements. In other words, in accordance with the findings of Chen (2007), the competition pressure of the Spanish savings banks on the domestic banks' behavior resulted in a stabilizing of the banking system due to an improvement in knowing the customers (that is, less asymmetric information problems).

Nonetheless, the Cajas failed to take advantage of this favorable environment, basically due to their organizational underperformance, and ended up becoming extinct after the CFG of 2008. The cause of this underperformance of the Cajas is essentially explained by the singular ownership structure that the Cajas had, in which unlike commercial banks there were no private shareholders. In fact, the absence of private partners decreases economic outcomes since there are no pecuniary interests (Ianotta et al., 2007; La Porta et al., 2002), although it does enable prioritizing the achieving of several (employment, fighting poverty or civic) welfare objectives (Burgess \& Pande, 2005; Dinç, 2005).

In this vein, the literature agrees that the absence of professional and independent governance which makes decisions in the line with the codes of good corporate practices was the major weakness of the Cajas (Ruiz et al., 2016). The governing board structures of the Cajas are mostly made up of ex-politicians or directors with strong political connections, who relaxed both the management standards and the internal controls (San-Jose et al., 2014). This political interference resulted in a substantial increase of the credit risk of the loan portfolio of the Cajas (Sagarra et al., 2015). In practice, the political power interceded so that financing was conceded to firms which were the economic drivers in their regions and that employed many workers (that is, they bonded the population of a region). This was financing which, would have been denied based exclusively on the economic data of these firms. Therefore, the Cajas became financers of firms related to the regional political power, with cases of generalized corruption and a form of management where political criteria prevailed more than strictly economic criteria.

All of this aggravated the loan default rates and solvency problems of the Cajas (Illueca et al., 2014). This solvency was traditionally less than that of commercial banks due to (beyond worsening governance) the Cajas' small size (lower economies of scale) and the greater geographic concentration of their customers (that is to say, less geographic diversification of the loan portfolio), in the majority of cases limited to a sole region/province.

The Cajas could not survive the GFC of 2008 -which overlapped with the burst of the Spanish real estate bubble-demonstrating that they were the most vulnerable part of the Spanish financial system (Martin et al., 2018). Basically, the Cajas faced these two crises with a high credit exposure in the real estate sector, a loan portfolio which was geographically very concentrated, a small size and stultified and inefficient organizational structures - even, in some instances, with cases of corruption in their management. Consequently, during the period 2009-2014 all the Cajas (except two small saving banks: Pollensa and Ontinyent) collapsed and had to be involved in M\&A processes to survive. Therefore, we can state that the Cajas disappeared in Spain during this process of financial restructuring.

Basically, the spirit of the restructuring process safeguarded the sustainability of the Spanish financial system by encouraging the concentration (that is, increasing the size, economies of scale, efficiency and profitability of the resulting entities) and recapitalization (that is, increasing the solvency). To do so, several measures were adopted, being highlighted: (i) the creation of the Fund of Orderly Bank Restructuring (FROB) by which public financial support was channeled to the financial sector (Royal Decree-law 9/2009) and (ii) the reform of the legal regime of the Cajas (Royal Decree-law 11/2010) to foster their capitalization and professional governance -supplemented by the Law 26/2013 that harmonized the Cajas' corporate form. Both laws became highly relevant because they enabled the Cajas to change from being private foundations (that could not issue capital) to credit institutions with access to capital markets (which improves their solvency) and private shareholders who monitor the board and the TMT by applying criteria of economic and managerial efficiency.

The restructuring process reduced the number of financial entities from 59 ( 45 Cajas and 14 commercial banks) in 2009 to 18 (all of them commercial banks) by the middle of 2013. The details of the M\&A operations as well as the public schemes carried out in the Spanish financial reform are shown in the following Table 1:

\subsection{Hypotheses development}

Traditional economic theory posits the benefit of M\&A processes in terms of increasing the synergies and reducing the costs through economies of scale (Bena \& Li, 2014). M\&A also decrease the competence in a sector and favor the creation of larger organizations which definitively contribute to increasing the profitability, solvency and probability of survival of the organizations. For this reason, bank consolidation via M\&A is implemented as one of the first measures to address banking crises (Vander Vennet, 2002).

Further than addressing banking restructurings, M\&A are really an opportunity for banks because they lead to competitive advantages derived from their smaller size. Note that, despite higher coordination costs associated with larger banks, the performance of lending organizations is strongly linked to their size through alternative ways. Firstly, larger banks have a greater geographical 
diversification of the credit risk and a lower exposure to idiosyncratic local risks because they have more offices out of their core area (Goetz et al., 2016). However, the positive effect of the geographic expansion on the bank risk may be less than that expected due to the lower ability of lenders to monitor loans in unknown environments. Secondly, larger financial entities have greater economies of scale since they can distribute their operational fixed cost linked to central services, branches, technologies and buildings (among others) between a greater number of transactions. Thirdly, larger banks obtain funds at a lower interest rate in the interbank credit market since they are considered less risky (Martin et al., 2018). The access to the financial markets in better economic conditions increases the profit margin to larger banks, which results in an increase of their profitability. Given that the current environment of negative interest rates is pressuring the margin of the banking sector, maintaining the margin becomes a crucial factor to ensure the survival of lending organizations. Fourthly, the creation of larger banks is also supported from the point of view of organizational innovations and knowledge. As Leal-Rodriguez et al. (2015) suggested, this is due to the larger firm size and the greater likelihood of developing innovations and knowledge within the organization. This is mainly explained by the Critical Mass Theory and leads the banks to develop sustainable competitive advantages, profitability and the probability of long-term survival to a greater extent.

On the other hand, M\&A also benefits the banks by substantially reducing the competition in the sector. Conventional wisdom suggests that decreasing competition reduces the risk taken by lenders (e.g., Allen \& Gale, 2000; Cordella \& Yeyati, 2002; Matutes \& Vives, 2000), which impacts positively on the banking performance by increasing the present value of future profits. In fact, the literature finds that in more open environments banks charge lower interest rates (Rice \& Strahan, 2010) and increase the supply of mortgage credit and approval rates (Favara \& Imbs, 2015). Consequently, in a constrained environment, such as the current one, where the traditional banks are being threatened by the entry of new competitors (Fintech) in the industry, M\&A arises as a powerful defensive strategy. Therefore, the abovementioned advantages from M\&A should lead -at least, from a theoretical point of view-to an improvement of the competitiveness, operational efficiency and profitability of the banks, which increase their solvency and resilience in periods of economic stress and uncertainty.

Contrary to this view, recent research surprisingly questions the positive effect of M\&A and the decrease of competition on banking outcomes. In this vein, Arping (2019) suggests that although a greater competition negatively affects banking performance through lower profit margins, there is also a positive impact via lower levels of the risks taken by banks. Similarly, Tanna et al. (2017) find that, although the financial liberalization has a double effect on banking productivity, the positive effect outweighs the negative effect. In this vein, Iannotta et al. (2007) show that state-owned banks are often less profitable and efficient. Hryckiewicz (2014) finds that government interventions reduce market discipline and lead to inefficient banking structures that negatively impact on banking sector stability and risk. Also, Hoshi and Kashyap (2010) show that the government policies carried out to recapitalize the banks in Japan during the banking crisis of 1990s led to a severe recession. Accordingly, conversely to what conventional wisdom suggests, restructuring reforms through M\&A may negatively impact on the banking performance.

Consequently, given that there is no consensus in the literature concerning the impact of competition on banking outcomes, the effects on the efficiency of M\&A linked to the Spanish financial restructuring system remain unknown. This is even more so when, as Casu and Molyneux (2003) stated, the effects of M\&A on the efficiency of a banking system depend on the institutional environment (such as the regulatory framework, public policies and the economic context) and the specific banking strategies implemented. In other words, the literature shows that the results of financial restructurings are country-dependent. This context effect is particularly important in Spain, where two institutional lending regimes coexist: (i) commercial and (ii) savings banks (Salas \& Saurina, 2002).

Therefore, on the basis of the foregoing arguments from the traditional approach, we expect the M\&A process linked to the Spanish restructuring financial system to have fostered the competitiveness of the banks through an increase in their efficiency. In other words, we presume that at the end of the banking restructuring the efficiency of the financial system was higher than at the beginning of the GFC of 2008. Accordingly, our first Hypothesis states that:

Hypothesis 1. The efficiency of Spanish lending organizations decreased during the global financial crisis, but they increased their efficiency in the subsequent period of the banking reform.

To assess the effects of the banking system reform on the bank solvency over time, we use the non-performing loans ratio. As mentioned before, the GFC of 2008 triggered the collapse of most Spanish savings banks, which had to be bailed out by the government and after involved in M\&A with commercial banks. Not surprisingly, the delinquency rate of Spanish financial systems reached new highs, surpassing 13.77\% in 2013 (Ruiz et al., 2016). These non-performing loans were heavily concentrated in the construction and real estate sectors and mostly originated by the Cajas which severely suffered from the Spanish subprime lending since, unlike the commercial banks that obtain most profit abroad, they only operate in Spain (Ruiz et al., 2016). Given that the loan defaults immediately cause losses and decreases the profit and equity valuation of the lender, we expect there to be a negative relationship between the ratio of non-performing loans to total loans and the economic outcomes (efficiency) of banks.

However, the negative effect of non-performance loans on banking outcomes is likely to be non-linear since loan delinquency depends to a large extent on the economic cycle, being substantially greater during a recession (Climent-Serrano, 2019). In other words, the non-performing loans ratio rises as the financial recession progresses. Consequently, we expect the negative effect of non-performance loans on banking efficiency to be enhanced during an economic crisis and banking reform periods, and decrease after an M\&A banking restructuring process. In fact, in the economic boom years back in 2002-2007 there was a strong growth of loans in Spain, but the delinquency rates remained around 0\%, in part because the numerator outgrew the denominator (Ruiz et al., 2016). Conversely, in the wake of the GFC (2008) the growth rate of the delinquency ratio in Spain was 358\%, non-performing loans attaining $3.7 \%$ of total assets. The delinquency ratio surpassed 13\% in 2013 and then began to decrease until it reached in 2018 similar levels to those existing prior to the GFC. Therefore, we have the following hypotheses: 
Hypothesis 2. A higher non-performing loans ratio negatively impacts on the efficiency of banks.

Hypothesis 2a. The negative impact of the non-performing loans ratio on efficiency is higher during the global financial crisis, but decreases in the period subsequent to the banking reform.

\section{Data and methodology}

\subsection{Sample description}

To build the database used in this study we use information from two different data sources. First, the data on commercial banks and savings banks was collected from the data repository of the Spanish Banking Association of Private Banks (AEB) and Spanish Confederation of Savings Banks (CECA), respectively. Second, country level macroeconomic data related to the gross domestic product (in euro and percentage annual growth) from the World Bank databases.

Since our objective is to analyze the productivity changes over time in the Spanish financial intermediary industry, our research period is from 2005 to 2016. Therefore, we carried out an analysis before, during and after the financial crisis and the Spanish banking restructuring process, which strengthens the validity of our findings.

To analyze the impact of the Spanish financial restructuring process on the efficiency change over time and given that M\&A reduce the number of banking institutions, we consolidate sample lending organizations that were merged or acquired in any year between 2010 and 2013 and consider them to be a single firm as if the merger or acquisition took effect in the year 2005. For example, if banks A, B and C merge in 2010, then data for them are added for each year of the period 2005-2009, considering them as a single lending organization for the entire sample period (2005-2016).

Accordingly, from the more than 60 financial entities (both commercial and savings banks) which operated in Spain at the beginning of 2005, the M\&A activities that were promoted and supported by the Spanish government and the EU commission brought about a dramatic fall in the number of financial intermediaries, only 18 banks remaining by 2016 (see Table 1). Therefore, the sample considered in this paper has 18 lending organizations for a 12-year-period (2005-2016), resulting in 216 observations.

\subsection{Methodology}

\subsubsection{First-stage DEA efficiency estimate}

As previously argued, we perform a two-stage analysis. First, the MFI efficiency scores are estimated by using DEA. This efficiency model was first proposed by Farrell (1957) and then improved by Charnes et al. (1978) and Banker et al. (1984). Conversely to parametric efficiency statistic models, such as Stochastic Frontier Analysis (SFA), DEA is a non-parametric method that does not impose a specific structure on the shape of the efficient frontier; this being its main advantage (Drake et al., 2006). However, a non-parametric treatment of the efficiency frontier relies on general regularity properties, such as monotonicity, convexity and homogeneity.

Thereby, DEA models enable assessing an MFI's performance relative to a 'best practice' frontier (Farrell, 1957). This method basically ranks, by comparison between peers, the lending organizations from higher to lower efficiency scores and also allows defining the optimal situation as a minimization input or maximization output problem.

The first version of DEA assumes constant returns to scale (CRS), i.e., a change in inputs is followed by a change in the same proportion of the outputs. In this paper, we employ an input-oriented DEA model with variable returns to scale (VRS) developed by Banker et al. (1984). That is to say, the VRS relaxes the constant returns to scale assumption and allows for the possibility that the banks' production technology may exhibit increasing, constant, or decreasing returns to scale. Note that a novel DEA approach has arisen in the last years that fits M\&A restructuring research well, namely inverse DEA (Frija et al., 2011; Wei et al., 2000). Unlike the traditional DEA model, whose goal is to estimate the efficiency score of each DMU, inverse DEA assumes the efficiency levels as predefined parameters and its aim is to calculate the inputs and outputs required to reach these given efficiency scores.

Consequently, inverse DEA can redistribute the multiple inputs and multiple outputs inherited from pre-restructuring DMUs between post-restructuring DMUs (Amin et al., 2017). This capacity makes inverse DEA the preferable method to design and drive the M\&A process, suggesting the resulting consolidated entities that achieve the predefined target efficiency levels. Nevertheless, the inverse DEA model cannot be applied to evaluate an already made banking consolidation reform since the resulting entities are created externally to the model - in our case by the financial authorities. In other words, given that in the Spanish banking restructuring the financial institutions are merged under geographical, political and top management team's affinity criteria, but not on the base of optimizing the efficiency of the resulting banks, it is not possible to apply inverse DEA approach.

We perform an input-oriented VRS model since our presumption is that the managers of MFIs have more control over inputs than outputs. Basically, this model provides an efficiency score for $n$ number of DMUs by using $m$ outputs and $s$ inputs as presented below:

$$
\theta=\max _{u, y} \frac{\sum_{r=1}^{s} \mu_{r} y_{r o}}{\sum_{j=1}^{m} v_{j} x_{j o}}
$$

subject to,

$$
\frac{\sum_{r=1}^{s} \mu_{r} y_{r i}}{\sum_{j=1}^{m} v_{j} x_{j i}} \leq 1, \quad i=1,2, \ldots, n
$$




$$
\mu_{r}>0, v_{j}>0, \text { for all } r, j
$$

where the $j$ DMU consumes $x_{j i}$ inputs in order to produce $y_{r i}$ outputs, $\mu_{r}$ and $v_{j}$ being the weights of the outputs and inputs, respectively, which have to be $>0$ (Cooper et al., 2011). The technical efficiency measures will be ranked between 0 and 1 , taking the value 1 the DMUs located on the production frontier; that is, the most efficient observations.

One of the more controversial decisions for conducting a DEA model in financial intermediation research is linked to the selection of the efficiency model approach (production or intermediation). Under the production approach, banking institutions are considered as loans and services production units. In contrast, the intermediation approach defines the lending organizations as intermediaries between providers of funds and users of funds. Consequently, the main point of dispute between both approaches is how to classify deposits because of, in the former, the deposits being viewed as outputs while in the intermediation approach they are seen as an input variable.

For this reason, the production approach is often used in environments where the financial intermediaries do not collect savings deposits, as is customary in the microfinance industry where the microfinance institutions are mostly funded by private donors and governments. Unlike microfinance, lending organizations around the world, including those intermediaries which have a more social profile, such as the Spanish savings banks, spend much of their time attracting financial resources from the private sector and financial markets. Accordingly, it seems reasonable to think that using the intermediation approach, where deposits are converted into loans (Kao \& Liu, 2014), is more suitable in the Spanish context. Another argument to support this approach is due to considering the interest expense, which accounts for a large proportion of a bank's costs. Hence, in accordance with Banker et al. (2010) we use the intermediation approach.

The selection of inputs and outputs is another key point of a DEA efficiency model. However, there is not a general agreement in the banking literature about which are the most appropriate input and output variables (Ahn \& Le, 2014). Thereby, we use an income-based approach to select the input and output variables since both commercial banks and Cajas operate as profit maximizing organizations, despite the Cajas being institutionally defined as non-profit lending intermediaries. In practice this approach considers the lenders as business units that try to generate revenue from the total costs incurred from running the business. Consequently, following the banking literature (e.g., Sturm \& Williams, 2004; Das \& Ghosh, 2006; Banker et al., 2010) we consider both the interest revenue and non-interest operating revenues (commissions, brokerage and operating fees) as output variables, and interest expense and other operating expense as inputs. Note that other operating expenses include employee remunerations, depreciations and rentals.

Fig. 1 shows the evolution of the input and output variables throughout the study period (2005-2016). Both interest revenues and interest expenses follow a rising trend until the outbreak of the GFC at the end of 2008, when they reach their peak. From 2009, the central banks implemented an expansive monetary policy to respond to the financial and debt crises which sharply decreased the official interest rates. As a result, both the interest revenues and interest expenses of the financial intermediation sector gradually fell, which negatively impacted on the banks' commercial margins. In fact, the reduction of interest rates was so severe that the curve of other operating expenses (employee remunerations, depreciations and rentals) surpassed the interest expenses, which remained the same from then on -note than in 2012 there is a peak in other expenses caused by the increase of redundancy costs due to the massive job cuts linked to M\&A activities. This is one of the main problems that the banking industry has been suffering in recent years and which has forced the banks to increase their efficiency and productivity - also their solvency, of course - for their long-term survival.

\subsubsection{Second-stage truncated regression}

To analyze the impact of the Spanish banking reform on the efficiency of the banking system, we run a set of regressions where the dependent variable is the efficiency scores obtained in the previous DEA efficiency models. Banker and Natarajan (2008) suggest that a

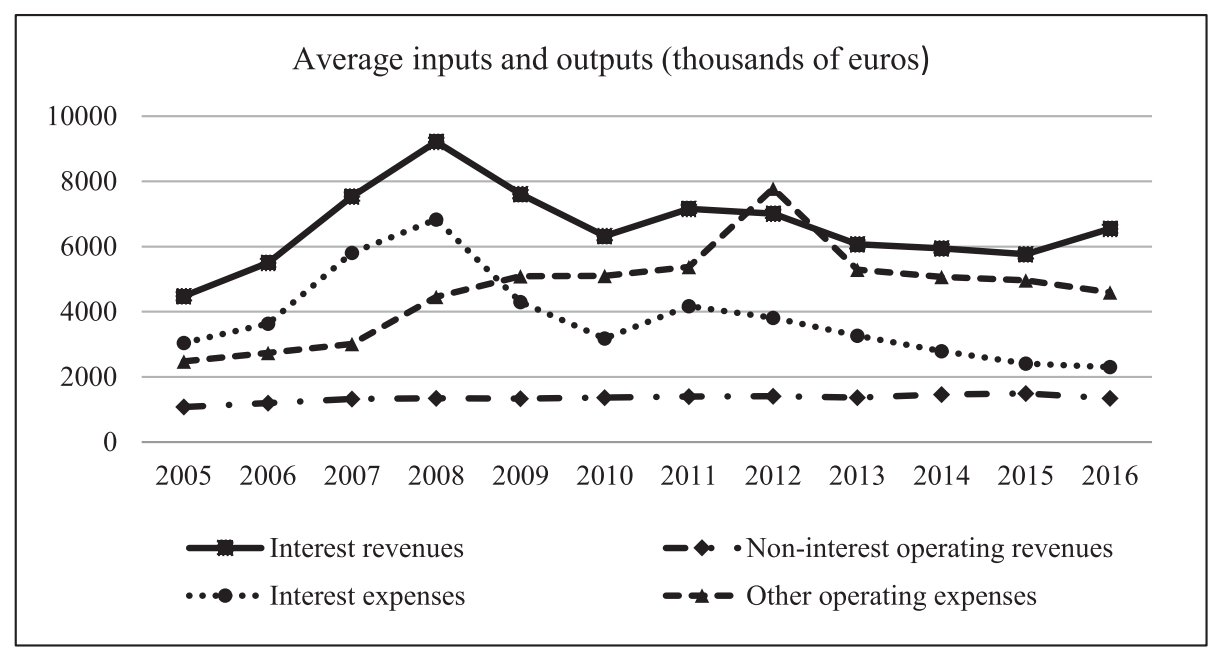

Fig. 1. Evolution of input and output variables. 
DEA model followed by maximum likelihood estimation yields a consistent estimator that performs at least as well as parametric models in the estimation of the effect of the contextual factors on the efficiency measures. This therefore supports, from a theoretical point of view, the two-stage approach followed here.

Nevertheless, given that the ordinary least square (OLS) regression makes biased and inconsistent estimations with censored - limited to [0,1]- dependent variables (Greene, 2004), we apply a panel Tobit regression for parameter estimations in this second stage. Additionally, in accordance with Fernandez-Val and Weidner (2016), we perform a random effect estimation Tobit regression since using fixed effects analysis causes incidental parameter problems and biased outcomes. Indeed, in fixed effect Tobit regression a problem arises related to the distribution of the disturbance variance estimator (Greene, 2004).

Therefore, we consider the following general panel data Tobit model:

$$
\begin{aligned}
& y_{i, t}^{*}=\beta_{0}+\beta_{1} Y E A R_{i, t}+\beta_{2} Y_{E A R_{i, t}} Y_{E A R_{i, t}}+\beta_{3} N P L R_{i, t}+\beta_{i} X_{i, t}+u_{i, t} \\
& y_{i, t}=\left\{\begin{array}{l}
y_{i, t}^{*}, \text { if } y_{i, t}^{*}<1 \\
1, \text { otherwise }
\end{array} i=1, \ldots, N \text { and } t=1, \ldots, T\right.
\end{aligned}
$$

where the $i$ subscript denotes the cross-sectional dimension and $t$ the time-series dimension. The dependent variable, $y_{i t}$ is the efficiency score obtained from the DEA for bank $i$ in the year $t, Y E A R_{i t}$ the number of the years passed since 2004 (base year) for bank $i$ at time $t$, $N P L R_{i t}$ the percentage of non-performing loans out of total loans for bank $i$ at time $t, X_{i t}$ the vector of control variables for bank $i$ at time $t$, and $u_{i t}$ is the error term.

Following Banker et al. (2010), including the variable YEAR - the number of years elapsed since 2004- and also its quadratic transform $\left(\mathrm{YEAR}^{2}\right.$ ) enables testing the non-linear and possibly non-monotonic trend in productivity over two distinct periods: (i) during the financial crisis and (ii) the period of bank restructuring and recovery following the financial crisis. As justified previously in Section 2, we expect the efficiency of the Spanish financial system to decline during the financial crisis, but improve during the period following that crisis. Consequently, since we expect a parabola-shaped time trend, the coefficients of YEAR and YEAR ${ }^{2}$ should be negative and positive, respectively.

Regarding the matrix of the control variables $\left(\mathrm{X}_{\mathrm{it}}\right)$, we include two types of variables. On the one hand, we introduce several bankspecific variables. Firstly, we control for the bank size and leverage by using the log of total interest income and debt equity ratio, respectively. Secondly, we also include a dummy variable (M\&A) to control whether a lending organization has participated in the M\&A (value 1) or not (value 0). Additionally, we consider a dummy variable (FINANCIAL SUPPORT) to capture if a lending organization has received financial support by the Spanish government and/or the EU commission (value 1) or not (value 0). Note that in the midst of the global financial crisis, the financial authorities opened ad hoc liquidity facilities and institutional support to ensure safety for depositors and avoid capital flight and banking bankruptcy. Finally, we also control by the financial intermediary ownership structure through a dummy variable (BANK) that takes the value 1 in the case of the original lending organization being a bank and, 0 if it was a Caja. This variable aims to separate the entities that are integrated in a bank or in a Caja since the culture and administrative organization of the resulting entities of the M\&A are determined by the dominant firms of these processes. As argued in Section 2, unlike commercial banks, the Cajas prioritize welfare objectives (Burgess \& Pande, 2005; Dinç, 2005) that lead to a laxer organizational culture which is less oriented toward economic incentives.

On the other hand, given that the macroeconomic shocks have a powerful effect on the banking sector, country-level variables are also included in our model. We introduce the gross domestic product (GDP) per capita and unemployment rate to capture the institutional and macroeconomic environment since banking institutions operating under more open institutional frameworks and with greater macroeconomic and legal stability are more likely to achieve high efficiency levels (Chortareas et al., 2012).

To attain a deeper understanding of the effect of the banking reform -and the resulting upsurge in concentration and competence levels-on the banks' efficiency, we explore another sort of regressions since the efficiency score obtained by a bank is likely to be affected by the previous efficiency levels. In other words, in our model there is an inter-temporal effect due to the efficiency at time $t$ being dependent on the efficiency at time $t$-1. Accordingly, we re-estimated our model by introducing the lagged efficiency score as an independent variable. To better account for the possibility of lagged effects, we employed panel corrected standard errors (PCSEs) estimations to handle a possible contemporaneous correlation of the errors (i.e., being correlated across firms within the same time period) and heteroskedasticity (i.e., having unequal variances across different subsets of banks). In a panel data design, error terms may not be independent among different time periods, resulting in a possible serial correlation problem. This means that for each individual bank the association between independent and dependent variables in the last year of analysis could be driven by (or at least be correlated with) the relationship between variables in the previous year and so forth. Hence, through PCSEs we also obtained estimations with lagged dependent variables as controls.

Nevertheless, since our dependent variable (efficiency score) is limited in its range [0, 1], following Banker et al. (2010), we calculate an inefficiency measure through the inverse proportion of efficiency ratios. Thereby, it is possible to carry out a PCSE estimation while keeping the rank provided by DEA analysis.

Accordingly, we also specify the following PCSE regression for the second stage estimation:

$$
y_{i, t}^{*}=\beta_{0}+\beta_{1} y_{i, t-1}^{*}+\beta_{2} Y E A R_{i, t}+\beta_{3} Y E A R_{i, t} Y E A R_{i, t}+\beta_{4} N P L R_{i, t}+\beta_{i} X_{i, t}+u_{i, t}
$$




\section{Results}

\subsection{Main results}

Table 2 provides the average efficiency scores for each of the financial groups that resulted from banking consolidations (via M\&A) during the period 2005-2016. To analyze the evolution of the banking efficiency measurements, we split the sample into three periods: before, during (years 2011-2012) and after the Spanish banking reform. As depicted in Table 2, the financial entities that benefited to a greater extent from banking consolidation were the Cajas. These entities, such as LiberBank or Bankia, had the lowest efficiency scores during the years 2011-2012 (0.2527 and 0.4934 respectively), increasing x2 and x1.7 the average efficiency levels during the period after the banking reform. This highlights the convenience and advantages that M\&A brings about for the Spanish financial system. The effects of M\&A on the efficiency of the Cajas cannot be directly observed when the Cajas were integrated into a commercial bank -such as happened with BBVA, which absorbed six Cajas, see Table 1- which mostly had a more robust financial health and higher levels of international competitiveness. In fact, the efficiency of Banco Santander, one of the most relevant commercial banks worldwide and which was not involved in M\&A with any Cajas, remained constant -with an average of 0.85 and a minimum of 0.81 during the banking reform-during the period analyzed.

The results of the second stage of our empirical analysis are presented in Table 3. The first set of regressions focus on analyzing the impact that the Spanish banking reform has on the efficiency of the financial system (see Models 1, 2 and 3). As can be seen in Table 3, the number of the years passed since the base year 2004 (YEAR) has a negative effect on the banking efficiency, but it becomes a positive impact after the banking reform $\left(\mathrm{YEAR}^{2}\right)$. These results suggest that the passage of time and the efficiency of the financial system are related through a U-shaped function. In other words, our findings therefore show that the efficiency of Spanish lending organizations decreases during the global financial crisis, but increases in the period subsequent to the banking reform. Therefore, confirming Hypothesis $H_{1}$, we find that the Spanish financial restructuring increased the efficiency of the Spanish financial system and contributed to improving the stability of lending intermediaries and the general economy. The confidence in the reliability of our findings was enhanced by the qualitatively similar results obtained by using alternative (Tobit and truncated) pooled and panel data regressions.

In addition, in order to fully understand the impact of the banking reform on the efficiency of the financial system we also analyze the effect of the non-performing loans ratio (NPLR) on efficiency. Basically, our analysis explores whether the impact of loan delinquency on the efficiency of the lending sector is lower after the banking reform. As shown in Table 3, we find that the percentage of non-performing loans out of the total loans has a negative influence on the banking efficiency. These findings support $\mathrm{H}_{2}$ and highlight the relevance of an adequate credit risk management as a key factor to avoid insolvency situations in lending organizations. In fact, as argued previously, the collapse of the Cajas was mostly caused by the lack of credit risk standards and internal control mechanisms.

Nevertheless, the effect of the NPLR on bank efficiency may be non-constant over time. Indeed, our findings suggest that there is a non-linear inverse U-shape relationship between the NPLR and banking efficiency. This result confirms $\mathrm{H}_{2 b}$ and shows that the impact of NPLR is higher during the year before the restructuring of the financial system and decreases afterward. In other words, we find that the banking reform substantially contributed to decreasing the NPLR in the Spanish financial system.

These results are supported by the findings of the literature for other countries with (very) different economic and institutional environments such as Korea (Banker et al., 2010). It is worth emphasizing that the M\&A activities fostered by the banking reform instantly increased the assets (a denominator of the NPLR) of the resulting lending organizations and thus decreased their NPLR. Of course, the increase of the assets caused by M\&A also benefited the solvency, commercial positioning and access to funding in the

Table 2

Efficiency measurements for each resulting financial group.

\begin{tabular}{|c|c|c|c|c|}
\hline \multirow{3}{*}{ Resulting financial groups } & \multicolumn{4}{|c|}{ Average efficiency scores } \\
\hline & \multirow{2}{*}{$\frac{\text { Entire period }}{(2005-2016)}$} & \multirow{2}{*}{$\frac{\text { Before banking reform }}{(2005-2010)}$} & \multirow{2}{*}{$\frac{\text { During banking reform }}{(2011-2012)}$} & \multirow{2}{*}{$\frac{\text { After banking reform }}{(2013-2016)}$} \\
\hline & & & & \\
\hline Bankia & 0.7577 & 0.7884 & 0.4934 & 0.8438 \\
\hline CaixaBank & 0.7261 & 0.7502 & 0.6548 & 0.7254 \\
\hline LiberBank & 0.3983 & 0.3735 & 0.2527 & 0.5083 \\
\hline Banco Ibercaja & 0.7303 & 0.8094 & 0.6495 & 0.6520 \\
\hline Banco Mare Nostrum & 0.7599 & 0.8343 & 0.6728 & 0.6919 \\
\hline KutxaBank & 0.7894 & 0.7635 & 0.8353 & 0.8053 \\
\hline Unicaja Banco & 0.7508 & 0.8055 & 0.7173 & 0.6854 \\
\hline Ontinyent & 0.8715 & 0.8393 & 0.8649 & 0.9231 \\
\hline Pollensa & 0.8060 & 0.8164 & 0.7922 & 0.7973 \\
\hline BBVA & 0.8184 & 0.8756 & 0.7653 & 0.7593 \\
\hline Banco Sabadell & 0.7370 & 0.8082 & 0.5777 & 0.7100 \\
\hline Bankinter & 0.7148 & 0.7970 & 0.5821 & 0.6577 \\
\hline Banco Popular & 0.7777 & 0.9087 & 0.7674 & 0.5864 \\
\hline Banco Santander & 0.8531 & 0.8482 & 0.8187 & 0.8777 \\
\hline Deutsche Bank & 1 & 1 & 1 & 1 \\
\hline Banca March & 0.7096 & 0.7508 & 0.5822 & 0.7114 \\
\hline Banco Pueyo & 0.9995 & 1 & 1 & 0.9985 \\
\hline Banco Cooperativo Español & 1 & 1 & 1 & 1 \\
\hline
\end{tabular}


Table 3

Effect of banking reform on banking efficiency.

\begin{tabular}{|c|c|c|c|c|c|c|}
\hline \multirow[b]{2}{*}{ Dependent variable: } & \multicolumn{2}{|c|}{ Pool Tobit regression } & \multicolumn{2}{|c|}{ Pool Truncated regression } & \multicolumn{2}{|c|}{ Panel Tobit regression } \\
\hline & Model 1 & Model 1b & Model 2 & Model 2b & Model 3 & Model 3b \\
\hline \multicolumn{7}{|l|}{ Bank efficiency } \\
\hline Year & $\begin{array}{l}-0.0370^{* * *} \\
(0.0133)\end{array}$ & $\begin{array}{l}-0.0746^{* * *} \\
(0.0172)\end{array}$ & $\begin{array}{l}-0.0379 * * * \\
(0.0104)\end{array}$ & $\begin{array}{l}-0.0583 * * * \\
(0.0139)\end{array}$ & $\begin{array}{l}-0.0426^{* * * *} \\
(0.0100)\end{array}$ & $\begin{array}{l}-0.0744 * * * \\
(0.0130)\end{array}$ \\
\hline Year*Year & $\begin{array}{l}0.0024^{* *} \\
(0.0010)\end{array}$ & $\begin{array}{l}0.0050 * * * \\
(0.0012)\end{array}$ & $\begin{array}{l}0.0020 * * * \\
(0.0007)\end{array}$ & $\begin{array}{l}0.0038 * * * \\
(0.0009)\end{array}$ & $\begin{array}{l}0.0026 * * * \\
(0.0007)\end{array}$ & $\begin{array}{l}0.0051^{* * *} \\
(0.0009)\end{array}$ \\
\hline Non-performing loans ratio & & $\begin{array}{l}-39.8736 * * * \\
(12.4360)\end{array}$ & & $\begin{array}{l}-16.0124 \\
(9.7760)\end{array}$ & & $\begin{array}{l}-31.5064^{* * *} \\
(9.5191)\end{array}$ \\
\hline Non-performing loans ratio*Year & & $\begin{array}{l}10.3223^{* * * *} \\
(2.8268)\end{array}$ & & $\begin{array}{l}4.6776 * * \\
(2.2123)\end{array}$ & & $\begin{array}{l}8.3118 * * * \\
(2.1569)\end{array}$ \\
\hline Non-performing loans ratio*Year*Year & & $\begin{array}{l}-0.6886^{* * *} \\
(0.1646)\end{array}$ & & $\begin{array}{l}-0.3529 * * * \\
(0.1273)\end{array}$ & & $\begin{array}{l}-0.5769 * * * \\
(0.1244)\end{array}$ \\
\hline Return on assets & $\begin{array}{l}3.1518^{* * *} \\
(0.3279)\end{array}$ & $\begin{array}{l}2.6522^{* * *} \\
(0.3341)\end{array}$ & $\begin{array}{l}3.7454 * * * \\
(0.2639)\end{array}$ & $\begin{array}{l}3.3061 * * * \\
(0.2734)\end{array}$ & $\begin{array}{l}3.2882^{* * *} \\
(0.4511)\end{array}$ & $\begin{array}{l}2.2496 * * * \\
(0.3952)\end{array}$ \\
\hline Return on equity & $\begin{array}{l}0.1228 \\
(0.1063)\end{array}$ & $\begin{array}{l}0.0367 \\
(0.1026)\end{array}$ & $\begin{array}{l}0.1338 * \\
(0.0741)\end{array}$ & $\begin{array}{l}0.0916 \\
(0.0718)\end{array}$ & $\begin{array}{l}0.1771^{* *} \\
(0.0794)\end{array}$ & $\begin{array}{l}0.1205^{*} \\
(0.0718)\end{array}$ \\
\hline Debt to equity ratio & $\begin{array}{l}0.0042^{* * *} \\
(0.0010)\end{array}$ & $\begin{array}{l}0.0032^{* * *} \\
(0.0010)\end{array}$ & $\begin{array}{l}0.0004 \\
(0.0008)\end{array}$ & $\begin{array}{l}-0.0001 \\
(0.0008)\end{array}$ & $\begin{array}{l}0.0014 \\
(0.0010)\end{array}$ & $\begin{array}{l}0.0007 \\
(0.0009)\end{array}$ \\
\hline Bank & $\begin{array}{l}0.0140 \\
(0.0326)\end{array}$ & $\begin{array}{l}-0.0135 \\
(0.0310)\end{array}$ & $\begin{array}{l}-0.0492 \\
(0.0309)\end{array}$ & $\begin{array}{l}-0.0818 * * * \\
(0.0290)\end{array}$ & $\begin{array}{l}-0.1960 \\
(0.1400)\end{array}$ & $\begin{array}{l}-0.1401 \\
(0.1107)\end{array}$ \\
\hline Financial support & $\begin{array}{l}-0.0101 \\
(0.0343)\end{array}$ & $\begin{array}{l}-0.0536 \\
(0.0328)\end{array}$ & $\begin{array}{l}-0.0350 \\
(0.0273)\end{array}$ & $\begin{array}{l}-0.0741^{* * *} \\
(0.0261)\end{array}$ & $\begin{array}{l}-0.0963 \\
(0.1469)\end{array}$ & $\begin{array}{l}-0.1137 \\
(0.1228)\end{array}$ \\
\hline$M \& A$ & $\begin{array}{l}-0.0697^{* *} \\
(0.0335)\end{array}$ & $\begin{array}{l}-0.0629 * * \\
(0.0312)\end{array}$ & $\begin{array}{l}-0.0139 \\
(0.0253)\end{array}$ & $\begin{array}{l}-0.0216 \\
(0.0229)\end{array}$ & $\begin{array}{l}-0.3090 * * \\
(0.1486)\end{array}$ & $\begin{array}{l}-0.2207^{*} \\
(0.1179)\end{array}$ \\
\hline Assets (Ln) & $\begin{array}{l}-0.0106 \\
(0.0068)\end{array}$ & $\begin{array}{l}-0.0013 \\
(0.0066)\end{array}$ & $\begin{array}{l}0.0042 \\
(0.0061)\end{array}$ & $\begin{array}{l}0.0114 * * \\
(0.0058)\end{array}$ & $\begin{array}{l}0.0571 * \\
(0.0296)\end{array}$ & $\begin{array}{l}0.0382^{*} \\
(0.0210)\end{array}$ \\
\hline GDP per capita (Ln) & $\begin{array}{l}0.0610 \\
(0.3059)\end{array}$ & $\begin{array}{l}0.3142 \\
(0.3121)\end{array}$ & $\begin{array}{l}0.2409 \\
(0.2394)\end{array}$ & $\begin{array}{l}0.2956 \\
(0.2465)\end{array}$ & $\begin{array}{l}0.0793 \\
(0.2307)\end{array}$ & $\begin{array}{l}0.3001 \\
(0.2221)\end{array}$ \\
\hline Unemployment rate & $\begin{array}{l}0.1196 \\
(0.2143)\end{array}$ & $\begin{array}{l}0.1196 \\
(0.2143)\end{array}$ & $\begin{array}{l}0.1430 * \\
(0.1937)\end{array}$ & $\begin{array}{l}0.1430 * \\
(0.1937)\end{array}$ & $\begin{array}{l}0.1943 \\
(0.2481)\end{array}$ & $\begin{array}{l}0.1943 \\
(0.2481)\end{array}$ \\
\hline Dummy variable year & Yes & Yes & Yes & Yes & Yes & Yes \\
\hline Number of observations & 216 & 216 & 168 & 168 & 216 & 216 \\
\hline F-test & $154.81^{* * *}$ & $184.32 * * *$ & $314.56 * * *$ & $409.61 * * *$ & $141.85^{* * *}$ & $259.05^{* * *}$ \\
\hline
\end{tabular}

Standard errors for the slope coefficients are in parentheses. ${ }^{* * *} \mathrm{p}<0.01,{ }^{* *} \mathrm{p}<0.05,{ }^{*} \mathrm{p}<0.1$.

financial markets of banks. Also, as the situation of the Spanish financial system was stabilizing and the economy was improving over time, the defaulted loans (a numerator of the NPLR) and, consequently, the NPLR decreased.

Therefore, we find that the banking systems reform via bank consolidation strengthened the banks' solvency by reducing the NPLR. Obviously, further than previous improvement, it needed to consider the qualitative advantages that M\&A brought about for the Spanish savings banks in terms of the professionalization of their credit risk management and recovering procedures, the elimination of political interferences and their geographical diversification loan portfolio, as argued previously.

\subsection{Robustness checks}

Two robustness tests are made to confirm our findings. Their results are also shown in Table 4. On the one hand, we re-estimate the previous models by including the lagged efficiency score as an independent variable. By doing so, we address the inter-temporal effect that exists in our models since the efficiency at time $t$ is dependent on the efficiency at time $t-1$. To this end, as argued in the methodology section, we apply panel corrected standard errors (PCSEs) estimations. Note that in this case the dependent variable is the inefficiency. As can be seen in Table 4, the previous results are confirmed by the PCSE regressions, suggesting that the banking system reform carried out in Spain increased the financial system's efficiency as well as its solvency through of a decrease of the non-performing loans ratio.

On the other hand, we carry out another robustness test as well by using the Simar and Wilson (2007) procedure. Basically, this is a two-stage DEA analysis in which the DEA scores are first evaluated and then regressed on potential covariates with the use of a bootstrapped truncated regression. Simar and Wilson (2007) sustain that the use of the Tobit regression in the second stage causes explanatory variables to be correlated with the error term as inputs and outputs are correlated with explanatory variables. To deal with these potential problems we run a double bootstrapped procedure (Algorithm II) that permits the valid inference while simultaneously generating standard errors and confidence intervals for the efficiency estimates. As shown in Table 4, the results from Simar and Wilson's (2007) procedure also confirm the parabola-shaped time trend and the progressive decline of the non-performing loans ratio after the banking reform.

These two robustness checks strengthen our findings and their implications. Additionally, these findings highlight the relevance of bank consolidations via M\&A as a preferential choice to meet banking crises since this government intervention increases both the efficiency and solvency of the banking sector, and thus the financial system's stability. 
Table 4

Robustness analysis.

\begin{tabular}{|c|c|c|c|c|}
\hline \multirow[b]{2}{*}{ Dependent variable: } & \multicolumn{2}{|c|}{ PCSE regression } & \multicolumn{2}{|c|}{ Simar \& Wilson } \\
\hline & Model 4 & Model 4b & Model 5 & Model 5b \\
\hline \multicolumn{5}{|l|}{ Bank efficiency } \\
\hline Lagged of inefficiency & $\begin{array}{l}0.3296^{* * *} \\
(0.1142)\end{array}$ & $\begin{array}{l}0.3438^{* * *} \\
(0.0925)\end{array}$ & & \\
\hline Year & $\begin{array}{l}0.3494^{*} \\
(0.2170)\end{array}$ & $\begin{array}{l}0.4814^{* *} \\
(0.1966)\end{array}$ & $\begin{array}{l}-0.0373^{* * *} \\
(0.0103)\end{array}$ & $\begin{array}{l}-0.0580 * * * \\
(0.0138)\end{array}$ \\
\hline Year*Year & $\begin{array}{l}-0.0193^{*} \\
(0.0117)\end{array}$ & $\begin{array}{l}-0.0261^{* *} \\
(0.0104)\end{array}$ & $\begin{array}{l}0.0020 * * * \\
(0.0007)\end{array}$ & $\begin{array}{l}0.0038 * * * \\
(0.0009)\end{array}$ \\
\hline Non-performing loans ratio & & $\begin{array}{l}83.1551 * * \\
(32.9015)\end{array}$ & & $\begin{array}{l}-16.4831 * \\
(9.8542)\end{array}$ \\
\hline Non-performing loans ratio*Year & & $\begin{array}{l}-18.2361^{* *} \\
(7.1844)\end{array}$ & & $\begin{array}{l}4.7571 * * \\
(2.2386)\end{array}$ \\
\hline Non-performing loans ratio*Year*Year & & $\begin{array}{l}1.1576^{* * *} \\
(0.3902)\end{array}$ & & $\begin{array}{l}-0.3560 * * * \\
(0.1292)\end{array}$ \\
\hline Return on assets & $\begin{array}{l}-9.4169^{* * *} \\
(1.7922)\end{array}$ & $\begin{array}{l}-6.5457^{* * *} \\
(1.5028)\end{array}$ & $\begin{array}{l}3.8292^{* * *} \\
(0.2885)\end{array}$ & $\begin{array}{l}3.3531 * * * \\
(0.2865)\end{array}$ \\
\hline Return on equity & $\begin{array}{l}-0.7541^{* *} \\
(0.3033)\end{array}$ & $\begin{array}{l}-0.7864 * * * \\
(0.2044)\end{array}$ & $\begin{array}{l}0.1414^{*} \\
(0.0746)\end{array}$ & $\begin{array}{l}0.0971 \\
(0.0723)\end{array}$ \\
\hline Debt to equity ratio & $\begin{array}{l}-0.0032^{*} \\
(0.0018)\end{array}$ & $\begin{array}{l}0.0025 \\
(0.0016)\end{array}$ & $\begin{array}{l}0.0004 \\
(0.0009)\end{array}$ & $\begin{array}{l}-0.0001 \\
(0.0008)\end{array}$ \\
\hline Bank & $\begin{array}{l}0.0451 \\
(0.0455)\end{array}$ & $\begin{array}{l}0.1550 * * * \\
(0.0521)\end{array}$ & $\begin{array}{l}-0.0487 \\
(0.0304)\end{array}$ & $\begin{array}{l}-0.0821 * * * \\
(0.0294)\end{array}$ \\
\hline Financial support & $\begin{array}{l}0.0235 \\
(0.0494)\end{array}$ & $\begin{array}{l}0.1731 * * * \\
(0.0637)\end{array}$ & $\begin{array}{l}-0.0342 \\
(0.0264)\end{array}$ & $\begin{array}{l}-0.0741^{* * *} \\
(0.0262)\end{array}$ \\
\hline M\&A & $\begin{array}{l}0.0213 \\
(0.0560)\end{array}$ & $\begin{array}{l}-0.0016 \\
(0.0487)\end{array}$ & $\begin{array}{l}-0.0136 \\
(0.0258)\end{array}$ & $\begin{array}{l}-0.0214 \\
(0.0228)\end{array}$ \\
\hline Assets (Ln) & $\begin{array}{l}0.0002 \\
(0.0112)\end{array}$ & $\begin{array}{l}-0.0298^{* * *} \\
(0.0104)\end{array}$ & $\begin{array}{l}0.0041 \\
(0.0060)\end{array}$ & $\begin{array}{l}0.0115^{* *} \\
(0.0057)\end{array}$ \\
\hline GDP per capita (Ln) & $\begin{array}{l}-2.2256 \\
(1.7817)\end{array}$ & $\begin{array}{l}-3.1597^{*} \\
(1.6614)\end{array}$ & $\begin{array}{l}0.2127 \\
(0.2453)\end{array}$ & $\begin{array}{l}0.2851 \\
(0.2481)\end{array}$ \\
\hline Unemployment rate & $\begin{array}{l}-0.0533^{*} \\
(0.0328)\end{array}$ & $\begin{array}{l}-0.0729 * * \\
(0.0291)\end{array}$ & $\begin{array}{l}0.0286 \\
(0.0312)\end{array}$ & $\begin{array}{l}0.0567 \\
(0.0431)\end{array}$ \\
\hline Dummy variable year & Yes & Yes & Yes & Yes \\
\hline Number of observations & 193 & 193 & 216 & 216 \\
\hline R-squared $\left(\mathrm{R}^{2}\right)$ & 0.7139 & 0.7999 & & \\
\hline F-test & $150.28 * * *$ & $329.80 * * *$ & $272.63^{* * *}$ & $363.17 * * *$ \\
\hline
\end{tabular}

Standard errors for the slope coefficients are in parentheses. ${ }^{* * *} \mathrm{p}<0.01,{ }^{* *} \mathrm{p}<0.05,{ }^{*} \mathrm{p}<0.1$.

\section{Discussion and conclusion}

In the wake of the GFC several financial institutions collapsed and were bailed out by governments and/or subjected to recapitalization and debt-restructuring schemes. The response to the GFC by governments and central banks was massive and unprecedented in both the US and Europe. The scale of government interventions was articulated by using different mechanisms for each country or economic area, but in the majority of the cases, these resulted in banking system reforms and bank consolidation with the aim of strengthening banks' solvency.

This paper analyzes the effects of the restructuring of the financial system through bank consolidation on the banking efficiency. We focus on the banking reforms carried out in Spain where the consequences of the GFC overlapped with an internal economic crisis due to the bursting of a real estate bubble, and governance problems and political interferences in the Cajas. The interventions of the European and Spanish authorities resulted in a banking reform that fostered M\&A among financial entities, and at the end of the process all the Spanish savings banks (except two) became involved in massive merger processes and transformed into commercial banks. In fact, the Cajas disappeared in Spain with this banking reform and there was a radical reduction in the number of lending organizations -from 59 to only 18 financial entities.

Our results show that the banking reform conducted by the Spanish government, with the support of the European authorities, to solve the collapse of most savings banks caused a positive impact on the banking performance in terms of both bank efficiency and bank solvency. This therefore implies that in the productivity and solvency of the Spanish banking sector there are two definite trends separated by the banking reform: (i) during the financial crisis and (ii) the period of bank restructuring and recovery following the financial crisis. Consequently, the banking reform contributed to improving the stability of lending intermediaries and the general economy in Spain, further avoiding an economic contagion to the rest of the euro area.

The practical implications of this research are relevant for governments and financial authorities as well as for banking management. Firstly, our findings support the financial authorities fostering bank consolidation through M\&A as a preferred banking restructuring mechanism. In line with Kizys et al. (2016), we find that the gains from government intervention outweigh the inefficiency caused by the increase of risk, the decrease of market discipline or the distortion of the competition in the sector. More importantly, bank 
consolidation via M\&A avoids the negative externalities of other public measures, an example being that caused by an injection of capital increasing the market share of zombie banks, despite zombie banks severely distorting the competition in the sector (Calderon \& Schaeck, 2016). In other words, banking reform via M\&A drives out unviable banks, which would only remain operating because of government support, from the financial intermediation market.

Therefore, since policymakers have not yet developed a clear guidance for addressing banking crises, our findings show that bank consolidation is a feasible alternative given its positive effects on both bank efficiency and bank solvency.

In addition, the positive effects that M\&A bring for banks may also impact positively on their customers. Thereby, the lower cost of capital caused by accessing the interbank market in better economic conditions, and the improvements in operational efficiency and solvency positions, should reduce the interest rates applied to borrowers. A greater financial products portfolio and better quality services are also presumed for larger and financially healthier banks, at the same time as an increase of the assurance of depositors in safeguarding their money. Nevertheless, these advantages linked to bank consolidation via M\&A may not be transferred to the customer side if banks monopolize an excessive market power and the banking authorities' control mechanisms fail.

Secondly, from the point of view of the banking management we support the literature that suggests that M\&A lead to more concentrated banking systems, which have a lower probability of systemic crises and a greater resilience to abnormal economic events (Diallo, 2015; Fu et al., 2014). Our results therefore contradict the findings of Schaeck et al. (2009) and Anginer et al. (2014) who show that there is a positive relationship between competition in the banking sector and systemic stability. These findings are very relevant in the current worldwide economic environment, which is strongly affected by the Covid-19 event. In this context, the financial authorities as well as the governments will be forced to strengthen the solvency of financial systems to ensure its survival, and M\&A arises as a viable alternative.

The main limitation of our research arises because it only addresses the Spanish banking reform and consequently the implications of our findings must be framed in the institutional and environmental context of Spain, which cannot be directly extrapolated to other countries or economic areas. This issue gains further importance if the findings of Beck et al. (2013) are taken into account. They affirm that the empirical evidence concerning the relationship between competition and banking stability is inconclusive and largely dependent on the sample and conditioning variables used. Therefore, with the aim of having more empirical evidence, future research should address the impact of banking reforms via M\&A on bank performance in different countries and institutional environments, but by analyzing each country separately.

\section{Authorship contributions}

Antonio Blanco-Oliver: Conception and design of study, acquisition of data, analysis and/or interpretation of data, Drafting the manuscript, revising the manuscript critically for important intellectual content, Approval of the version of the manuscript to be published (the names of all authors must be listed).

\section{Acknowledgements}

All persons who have made substantial contributions to the work reported in the manuscript (e.g., technical help, writing and editing assistance, general support), but who do not meet the criteria for authorship, are named in the Acknowledgements and have given us their written permission to be named. If we have not included an Acknowledgements, then that indicates that we have not received substantial contributions from non-authors.

\section{Appendix}

Table A.1Descriptive statistics

\begin{tabular}{|c|c|c|c|c|c|c|}
\hline Variable & $\mathrm{N}$ & Mean & St. Dev. & Min. & Median & Max. \\
\hline Interest expenses (in thousands) & 216 & 3,800 & 6,800 & 2.275 & 1,000 & 38,000 \\
\hline Other operating expenses (in thousands) & 216 & 4,700 & 9,100 & 7.020 & 1,200 & 49,000 \\
\hline Interest revenue (in thousands) & 216 & 6,500 & 13,000 & 10.612 & 1,700 & 61,000 \\
\hline Non-interest operating revenues (in thousands) & 216 & 1,300 & 2,800 & 1.555 & 290 & 13,000 \\
\hline Efficiency score & 216 & 0.7889 & 0.1751 & 0.1856 & 0.8018 & 1.0000 \\
\hline Non-performing loans ratio & 216 & 1.03 & 1.70 & -0.56 & 0.62 & 13.49 \\
\hline Return on assets & 216 & -0.0066 & 0.0344 & -0.2246 & 0.0002 & 0.2202 \\
\hline Return on equity & 216 & 0.0686 & 0.0994 & -0.3143 & 0.0716 & 0.8003 \\
\hline Debt to equity ratio & 216 & 15.1592 & 8.2755 & 0.1225 & 14.4442 & 44.1622 \\
\hline Assets (in millions) & 216 & 162.54 & 271.93 & 0.2601 & 58.6813 & $1,340.26$ \\
\hline GDP per capita (in millions) & 216 & 0.0231 & 0.0008 & 0.0213 & 0.0230 & 0.0243 \\
\hline Unemployment rate & 216 & 17.7670 & 6.4507 & 8.2325 & 19.7460 & 26.0950 \\
\hline
\end{tabular}




\section{References}

Acharya, V., \& Yorulmazer, T. (2007). Too many to fail -An analysis of time-inconsistency in bank closure policies. Journal of Financial Intermediation, 16(1), 1-31. Ahn, H., \& Le, M. H. (2014). An insight into the specification of the input-output set for DEA-based bank efficiency measurement. Management Review Quarterly, 64, 3-37.

Allen, F., Carletti, E., Goldstein, I., \& Leonello, A. (2015). Moral hazard and government guarantees in the banking industry. Journal of Financial Regulation, 1, 30-50. https://doi.org/10.1093/jfr/fju003

Allen, F., Carletti, E., \& Marquez, R. (2011). Credit market competition and capital regulation. Review of Financial Studies, 24(4), 983-1018. https://doi.org/10.1093/ $\mathrm{rfs} / \mathrm{hhp} 089$

Allen, F., \& Gale, D. (2000). Financial contagion. Journal of Political Economy, 108(1), 1-33.

Amin, G. R., Emrouznejad, A., \& Gattoufi, S. (2017). Modelling generalized firms' restructuring using inverse DEA. Journal of Productivity Analysis, 48, 51-61.

Arghyrou, M., \& Kontonikas, A. (2012). The EMU sovereign-debt crisis: Fundamentals, expectations and contagion. Journal of International Financial Markets, Institutions and Money, 22(4), 658-677.

Arping, S. (2019). Competition and risk taking in banking: The charter value Hypothesis revisited. Journal of Banking \& Finance, 107, 105609. https://doi.org/10.1016/ j.jbankfin.2019.105609

Bachiller, P., \& Garcia-Lacalle, J. (2018). Corporate governance in Spanish savings banks and its relationship with financial and social performance. Management Decision, 56(4), 828-848. https://doi.org/10.1108/MD-01-2017-0079

Banker, R. D., Chang, H., \& Lee, S. Y. (2010). Differential impact of Korean banking system reforms on bank productivity. Journal of Banking \& Finance, 34, $1450-1460$.

Banker, R. D., Charnes, A., \& Cooper, W. W. (1984). Some models for estimating technical and scale efficiencies in data envelopment analysis. Management Science, 30, 1078-1092.

Banker, R. D., \& Natarajan, R. (2008). Evaluating contextual variables affecting productivity using data envelopment analysis. Operations Research, 56(1). https:// doi.org/10.1287/opre.1070.0460

Beck, T., De Jonghe, O., \& Schepens, G. (2013). Bank competition and stability: Cross-country heterogeneity. Journal of Financial Intermediation, 22(2), 218-244. https://doi.org/10.1016/j.jfi.2012.07.001

Bena, J., \& Li, K. (2014). Corporate innovations and mergers and acquisitions. The Journal of Finance, 69(5), 1923-1960. https://doi.org/10.1111/jofi.12059

Berger, A. N., \& Udell, G. F. (2002). Small business credit availability and relationship lending: The importance of bank organisational structure. Economic Journal, 112(477), F32-F53.

Boot, A. W., \& Thakor, A. T. (2000). Can relationship banking survive competition? The Journal of Finance, 55(2), 679-713.

Brei, M., \& Schclarek, A. (2013). Public bank lending in times of crisis. Journal of Financial Stability, 9(4), 820-830.

Brown, S., Gray, D., \& Montagnoli, A. (2019). Credit supply shocks and household leverage: Evidence from the US banking deregulation. Journal of Financial Stability, 43, 97-115.

Burgess, R., \& Pande, R. (2005). Do rural banks matter? Evidence from the Indian social banking experiment. The American Economic Review, 95(3), 780-795.

Calderon, C., \& Schaeck, K. (2016). The effects of government interventions in the financial sector on banking competition and the evolution of zombie banks. Journal of Financial and Quantitative Analysis, 51(4), 1391-1436. https://doi.org/10.1017/S0022109016000478

Casu, B., \& Molyneux, P. (2003). A comparative study of efficiency in European banking. Applied Economics, 35(17), 1865-1876.

Charnes, A., Cooper, W. W., \& Rhodes, E. (1978). Measuring the efficiency of decision making units. European Journal of Operational Research, 2 , $429-444$.

Chen, X. (2007). Banking deregulation and credit risk: Evidence from the EU. Journal of Financial Stability, 2(4), 356-390.

Chortareas, G. E., Girardone, C., \& Ventouri, A. (2012). Bank supervision, regulation, and efficiency: Evidence from the European Union. Journal of Financial Stability, 8, $292-302$.

Climent-Serrano, S. (2019). Effects of economic variables on NPLs depending on the economic cycle. Empirical Economics, 56, 325-340.

Cooper, W. W., Seiford, L. M., \& Zhu, J. (2011). Data envelopment analysis: History, models, and interpretations. In W. Cooper, L. Seiford, \& J. Zhu (Eds.), Handbook on data envelopment analysis. International series in operations research and management science (Vol. 164). Boston, MA: Springer.

Cordella, T., \& Yeyati, E. L. (2002). Financial opening, deposit insurance, and risk in a model of banking competition. European Economic Review, 46(3), 471-485.

Das, A., \& Ghosh, S. (2006). Financial deregulation and efficiency: An empirical analysis of Indian Banks during the post reform period. Review of Financial Economics, 15(3), 193-221.

Diallo, B. (2015). Bank competition and crises revisited: New results. Economics Letters, 129, 81-86. https://doi.org/10.1016/j.econlet.2015.02.015

Dinç, I. S. (2005). Politicians and banks: Political influences on government-owned banks in emerging markets. Journal of Financial Economics, 77 , $453-479$.

Drake, L., Hall, M. J., \& Simper, R. (2006). The impact of macroeconomic and regulatory factors on bank efficiency: A non-parametric analysis of Hong Kong's banking system. Journal of Banking \& Finance, 30, 1443-1466.

Farrell, M. J. (1957). The measurement of productive efficiency. Journal of the Royal Statistical Association Studies, Series A (CXX), $253-281$.

Favara, G., \& Imbs, J. (2015). Credit supply and the price of housing. The American Economic Review, 105(3), 958-992.

Fernandez-Val, I., \& Weidner, M. (2016). Individual and time effects in nonlinear panel models with large N, T. Journal of Econometrics, 192(1), 291-312.

Frija, A., Wossink, A., Buysse, J., Speelman, S., \& Van Huylenbroeck, G. (2011). Irrigation pricing policies and its impact on agricultural inputs demand in Tunisia: A DEA-based methodology. Journal of Environmental Management, 92(9), 2109-2118.

Fu, X., Lin, Y., \& Molyneux, P. (2014). Bank competition and financial stability in Asia Pacific. Journal of Banking \& Finance, 38, 64-77. https://doi.org/10.1016/ j.jbankfin.2013.09.012

Goetz, M. R., Laeven, L., \& Levine, R. (2016). Does the geographic expansion of banks reduce risk? Journal of Financial Economics, 120(2), 346-362.

Greene, W. (2004). Fixed effects and bias due to the incidental parameters problem in the tobit model. Econometric Reviews, 23(2), $125-147$.

Gropp, R., \& Vesala, J. (2004). Deposit insurance, moral hazard and market monitoring. Review of Finance, 75-107.

Hoshi, T., \& Kashyap, A. (2010). Japan's financial crisis and economic stagnation. The Journal of Economic Perspectives, 18(1), 3-26.

Hryckiewicz, A. (2014). What do we know about the impact of government interventions in the banking sector? An assessment of various bailout programs on bank behavior. Journal of Banking \& Finance, 46, 246-265.

Iannotta, G., Nocera, G., \& Sironi, A. (2007). Ownership structure, risk and performance in the European banking industry. Journal of Banking \& Finance, 31(7), 2127-2149.

Illueca, M., Norden, L., \& Udell, G. F. (2014). Liberalization and risk-taking: Evidence from government-controlled banks. Review of Finance, 18, 1217-1257. https:// doi.org/10.1093/rof/rft023

Kao, C., \& Liu, S. T. (2014). Innovative applications of O.R. measuring performance improvement of Taiwanese commercial banks under uncertainty. European Journal of Operational Research, 235(3), 755-764.

Kizys, R., Paltalidis, N., \& Vergos, K. (2016). The quest for banking stability in the euro area: The role of government interventions. Journal of International Financial Markets, Institutions and Money, 40, 111-133.

Kumbhakar, S. C., Lozano-Vivas, A., Knox, C. A., \& Hasan, I. (2001). The effects of deregulation on the performance of financial institutions: The case of Spanish savings banks. Journal of Money, Credit, and Banking, 33(1), 101-120.

La Porta, R., Lopez-De-Silanes, F., \& Shleifer, A. (2002). Government ownership of banks. The Journal of Finance, 57(1), 265-301. https://doi.org/10.1111/15406261.00422

Lane, P. R. (2012). The European sovereign debt crisis. The Journal of Economic Perspectives, 26(3), 49-68.

Leal-Rodriguez, A. L., Eldridge, S., Roldan, J. L., Leal-Millan, A., \& Ortega-Gutierrez, J. (2015). Organizational unlearning, innovation outcomes, and performance: The moderating effect of firm size. Journal of Business Research, 68(4), 803-809.

Martin, E., Bachiller, A., \& Bachiller, P. (2018). The restructuring of the Spanish banking system: Analysis of the efficiency of financial entities. Management Decision, $56(2), 474-487$. 
Martinez-Miera, D., \& Repullo, R. (2010). Does competition reduce the risk of bank failure? Review of Financial Studies, 23(10), 3638-3664. https://doi.org/10.1093/ rfs/hhq057

Matutes, C., \& Vives, X. (2000). Imperfect competition, risk taking, and regulation in banking. European Economic Review, 44(1), 1-34.

Rice, T., \& Strahan, P. E. (2010). Does credit competition affect small-firm finance? Journal of Finance, 65(3), 861-889.

Ruiz, J. R., Stupariu, P., \& Vilariño, A. (2016). The crisis of Spanish savings banks. Cambridge Journal of Economics, 40, 1455-1477. https://doi.org/10.1093/cje/ bev078

Sagarra, M., Mar-Molinero, C., \& Garcia-Cestona, M. (2015). Spanish savings banks in the credit crunch: Could distress have been predicted before the crisis? A multivariate statistical analysis. The European Journal of Finance, 21(3), 195-214.

Salas, V., \& Saurina, J. (2002). Credit risk in two institutional regimes: Spanish commercial and savings banks. Journal of Financial Services Research, 22(3), $203-224$.

San-Jose, L., Retolazada, J. L., \& Torres-Pruñonosa, J. (2014). Efficiency in Spanish banking: A multistakeholder approach analysis. Journal of International Financial Markets, Institutions and Money, 32, 240-255.

Schaeck, K., Cihak, M., \& Wolfe, S. (2009). Are competitive banking systems more stable? Journal of Money, Credit, and Banking, 41(4), 711-734. https:/doi.org/ 10.1111/j.1538-4616.2009.00228.x

Simar, L., \& Wilson, P. W. (2007). Estimation and inference in two-stage, semi-parametric models of production processes. Journal of Econometrics, 136(1), 31-64.

Sturm, J. E., \& Williams, B. (2004). Foreign bank entry, deregulation and bank efficiency: Lessons from the Australian experience. Journal of Banking \& Finance, 28(7), $1775-1799$.

Tanna, S., Luo, Y., \& De Vita, G. (2017). What is the net effect of financial liberalization on bank productivity? A decomposition analysis of bank total factor productivity growth. Journal of Financial Stability, 30, 67-78.

Vander Vennet, R. (2002). Cost and profit efficiency of financial conglomerates and universal banks in Europe. Journal of Money, Credit, and Banking, 34(1), 254-282.

Vives, X. (2001). Restructuring financial regulation in the European monetary union. Journal of Financial Services Research, 19(1), 57-82.

Wei, Q., Zhang, J., \& Zhang, X. (2000). An inverse DEA model for inputs/outputs estimate. European Journal of Operational Research, 121(1), 151-163. 